\title{
Expectation of the Quality Culture in External Auditing: A Research about the External Audit Firms in Turkey
}

\author{
Engin Dinç and Yasin Şeker
}

\begin{abstract}
In this study, the understanding of the quality culture of the external audit firms which operate in Turkey has been tackled. A questionnaire form has been formed in order to define the understanding of the culture of quality. Target group of this prepared questionnaire is determined to be lead auditors. The questions concerning "the perception and expectations regarding the culture of quality" have been asked to the lead auditors. Questions in the questionnaire have been responded by 57 lead auditors from 57 different external auditing firms. In conclusion, it is concluded that the understanding of the lead auditors about the culture of quality in external audit firms was positive but their expectations could not met completely.
\end{abstract}

Index Terms-Auditor, quality culture in auditing, external audit, quality in auditing.

\section{INTRODUCTION}

Quality and the culture of quality are very important for the profession of external auditing like in most fields of profession.

In terms of independent/external auditing, quality means prioritizing the interests of the existing and potential information users who will decide upon the financial statements of a specific company. In other words, quality in external auditing is a concept; which boosts confidence of the parties engaging in the auditing reports, and reveals the need for externalauditing. A reliable conclusion can be obtained only if the auditing activities are done in accordance with certain standards. The confidence level among quality is directly related to that, whether the auditors and external audit firms comply with the quality control standards. [1] identifies the quality of auditing as the function of the probability that detecting the errors or intentional mistakes made by the auditor in the financial statements, and that being independent enough in reporting them.

As it can be seen in Fig. 1, there are 5 main factors which affect the quality of external auditing. Those factors are: (a) corporate culture of the auditing company, (b) talents and skills of the people who take part in the auditing team, (c) efficiency of the auditing process, (d) usefulness and reliability of the auditing reports, (e) factors out of the auditor's control [2].

Manuscript received July 19, 2015; revised February 6, 2016. This article has been derived from Yasin Şeker's unpublished postgraduate thesis which was conducted under the consultancy of Prof. Dr. Engin Dinç.A previous version of this paper was presented at the 2015 2nd International Conference on Marketing, Business and Management.

Engin Dinç was with Karadeniz Technical University, FEAS, Department of Business Administration, Trabzon, Turkey (e-mail: edinc@ktu.edu.tr).

Yasin Şeker was with Hitit University, FEAS, Department of Business Administration, Çorum, Turkey (e-mail: yasinseker@ hitit.edu.tr).

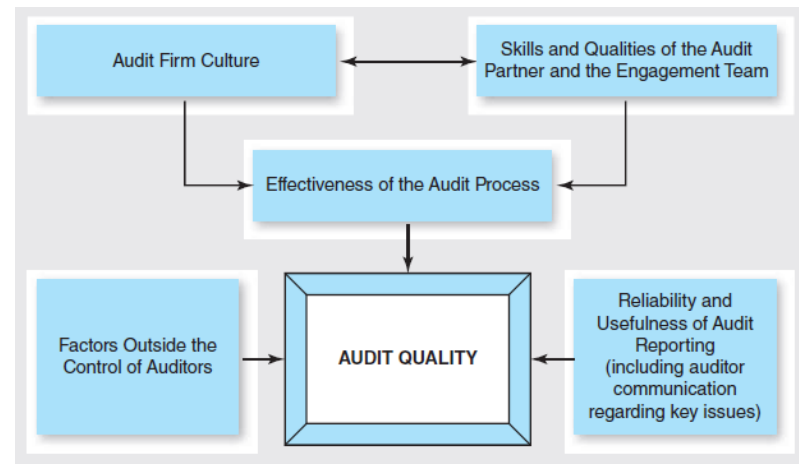

Fig. 1. Drivers of Audit quality.

Source: Johnstone et al., 2013: 15

When an organization sustains its existence in external environment and expands its capacity in managing internal affairs, all the efforts while learning the quality-related values represent the culture of quality of that organization. It takes time for a culture, which is a set of values and shared by all the individuals of an organization, to gain depth to a certain extent, and it requires education and learning as a whole team. According to [3], the culture of quality is a form of quality-related habits, beliefs and attitudes.

Increasing the quality in auditing, depends on interiorizing the principles and rules that are determined by inward and outward of the company, ranging from the co-lead auditor working in auditing companies and responsible for the vice-auditor to ordinary employees working in administration mechanism. All the employees working in the company pave the way for creating a culture of quality in the company if they adopt and interiorize these principles and remember them in every part of their careers. In the companies where the culture of quality is settled, the quality of audit will be pretty high too. Establishment of the culture of quality depends on the adoption of the fundamental principles of the philosophy of quality management in the company. These fundamental principles can be sorted as follows regardless of their order of importance [4]:

- Leadership of quality, efficient leadership and dependence of the leaders upon quality,

- Focusing on long-term objectives and consistency of aim,

- Providing the participation of employees and setting value on employee,

- Deciding on measurement with data and analysis-oriented approach,

- Feeling social responsibility,

- Recovering and learning continuously,

- Being request and need-oriented for customers,

- Partnership with suppliers and

- Process-oriented management 
Establishment of the culture of quality depends on the implementation of all principles written above in the company and adoption of them by all the employees in the company. These principles have been utilized while preparing the questionnaire which has been used in the study.

\section{LITERATURE REVIEW}

There are many studies which have been conducted on the subject of the quality in audit. In a study which have been conducted formerly, [1] conducted a research about the impact of the greatness of a company upon the quality of auditing. In accordance with the findings which have been obtained, when it comes to quality, big companies have been detected to be ahead of the smaller ones in terms of technological superiority, expertise skill, qualified employee and similar aspects, and it is concluded that the aforementioned presupposition to become invalid. In another study which has been done, [5] identified that the six big auditing companies priced on the auditing activities, having regard to the experience they have, by adding a premium than other local and small auditing firms. However, a relationship between quality and extra pricing could not be obtained as a result of the study. In other study concerning the quality in auditing, [6] conducted a research about, whether a relationship between the representation cost and a demand of a good quality of auditing of the firms exist or not. The relation between the greatness and quality of the auditing firms, and the relationship between the greatness of the firms and their improvement capacity has been identified. In other study concerning the subject of quality, [7] worked on the quality control examinations of the external audit firms and identified that the credibility of the external auditor has a substantial impact on the quality of auditing. In other study which has been conducted, [8] examined the quality of auditing service and focused on the methodological characters and basic legal problems in the areas belong to Latvia's internal auditing and external auditing control. In conclusion, [8] stated that the financial statements which are confirmed by the external auditor enabled the investments to grow, to boost the confidence upon financial markets, and to make contribution to the development of the region.

There are only a few of studies having been conducted concerning the quality of auditing in Turkey and couple of these existing studies are as follows: In a study which was conducted in 2003, [9] identified that there is no unit of quality control in the external audit firms and [9] also focused on its impact on the process of external auditing. The study has been conducted on total of 49 external audit firms and $57 \%$ of them registered to be having been implemented quality control and $76 \%$ of them have quality control policies and procedures and have been inspected. In a study which was conducted in 2007, [10] examined the supervisory system theoretically regarding the assurance of the quality of external auditing. In a doctoral thesis which is about the opinions and implementations regarding the independent quality of the external audit firms and external auditors, [11] concluded that the external audit firms have a positive attitude towards the activities of trade bodies and that they don't believe the control increase the quality but, that they believe the trade bodies should control the external audit firms. Furthermore, it was identified that the external audit firms generally don't have an initiative about composing a quality control system. In other doctoral thesis study, [12] examined 46 external audit firms and the role of Public Oversight Institution in increasing the quality of external auditing. In conclusion, they stated that creating the standards on quality control, code of conduct, independency, auditing and accounting of the external firms that are described to be as big should be granted to Public Oversight Institution. In another study, [13] conducted a research about the relationship between the efficiency of supervision for external audit firms and the quality of external auditing. In this context, the existing supervisions for the external audit firms have been examined in order to be evaluated. In conclusion, it is stated that there was not any supervision in Turkey which could increase the quality of external auditing until the establishment of Public Oversight Institution.

As it is seen, although there have been various studies conducted about quality, any study about the understanding of the culture of quality in the external audit firms could not be found.

\section{MATERIALS AND METHODS}

\section{A. Subject and Importance}

External audit firms should carry out the auditing activities in a way that they attach importance to quality. A qualified-auditing service depends on the level of understanding of quality in the company as well as the auditing standards that are implemented. There is not an empirical study in the literature concerning the culture of quality in the external audit firms. All the studies which have been conducted about the culture of quality are within the framework of total quality management. Considering this point of origin, this study has importance as being a first study which has been conducted about determining the understanding of the culture of quality in the external audit firms.

\section{B. Objective, Method and Hypotheses}

The main of objective of this study, is to determine the level of the understanding of the culture of quality in the external audit firms and to identify whether the existing culture of quality expectation is met or not.

Various models have been improved concerning the measurement of the quality of service like total quality index SERVPERF, critical events, benchmarking, group interview, SERVQUAL. One of the most frequently used method is SERVQUAL and this method is based on the comparing the perception with expectations [14]. In this study, SERVQUAL method has been used to be as revealing quality of the given service.

In the study two hypotheses whose answers to be sought have been determined. These hypotheses are given below.

$\mathrm{H}_{1}$ : The level of understanding of the culture of quality is high in the external audit firms.

$\mathrm{H}_{2}$ : The expectations concerning the culture of quality cannot be met completely in the external audit firms. 
The questionnaire which is used in the study is composed of 3 parts, the first part is composed of the questions identifying the individual and institutional features of the participants, the second part is composed of the questions concerning the culture of quality and the level of perception, the third part is composed of the questions concerning the expectation level scale of the culture of quality. A sample of questionnaire is given in the attached to the study.

In the given analysis, PASW Statistic 18 package program has been used. In the analysis of the data of the study, reliable coefficients of invariables (Cronbach's Alpha) have been primarily taken into consideration. Secondly, the auditors participated in the questionnaire and frequency distributions of data belong to the companies have been determined. Then, skewness, kurtosis, arithmetic average and standard deviation values which belong to the scales have been identified. Finally, hypotheses have been testes. While the first hypothesis was being tested, arithmetic average has been utilized. While the second hypothesis was being tested, "conjugate sample t test" has been utilized. The purpose of using this test, is to identify whether the expectations about the culture of quality in the external audit firms are met or not.

\section{Population}

The universe of the study is composed of the lead auditors who are responsible for quality in the external audit firms. Questionnaire technique was preferred as the method of data collection in the study. There were 112 external audit firms which were authorized in Turkey in May, 2014. At least one of the lead auditors from the External audit firms, was requested to fill the questionnaire forms The questionnaire forms have reached all the external audit firms. In conclusion, 57 external audit firms amongst a total of 112, have made comeback. In this case, the rate of comeback is registered as $\% 50,89$.

\section{Reliability}

Cronbach Alpha Coefficient method has been generally used in order to test the reliability of the scales. Alpha coefficient aims to measure internal consistency of the scales. This coefficient ranges between 0 and 1 . This ratio is generally expected to be higher than 0,60 in terms of its internal consistency reliability [15]. In this context, the reliability analysis has been implemented for the scales which take place in the questionnaire. Findings which belong to the reliability analysis are given in Table I.

TABLE I: RELIABILITY COEFFICIENTS OF THE SCALES

\begin{tabular}{ccc}
\hline \hline Name of the Scale & $\begin{array}{c}\text { Number } \\
\text { of Item }\end{array}$ & $\begin{array}{c}\text { Alpha } \\
\text { Coefficient }\end{array}$ \\
\hline $\begin{array}{c}\text { Questions About the Culture of } \\
\text { Quality Perception Scale } \\
\text { Questions About the Culture of }\end{array}$ & 13 & 0,842 \\
Quality Expectation Scale & 13 & 0,819 \\
\hline \hline
\end{tabular}

Alpha coefficients belong to the main variables which have been used in the research are given in Table I. As it is seen, alpha coefficient of all the scales are higher than 0,60 . It demonstrates the internal consistency of the scales used in the study and thus, it also demonstrates that the reliability is pretty high. This result demonstrates that these scales are reliable and that the characteristic which is desired to be measured is most probably true.

\section{EMPIRICAL RESULTS}

Introductory information belongs to the participants of this study, statistical data regarding the scales of the study and the information related to the analysis results are given under this heading.

\section{A. Personal and Institutional Features of Participants}

A couple of personal and institutional information of the participants of the questionnaire are summarized in the tables below.

TABLE II: INTRODUCTORY INFORMATION RELATED TO THE EXTERNAL AUDITORS

\begin{tabular}{|c|c|c|c|}
\hline Information & Group & Frequency & $\%$ \\
\hline Sex & $\begin{array}{l}\text { Male } \\
\text { Famale } \\
\text { Total } \\
\end{array}$ & $\begin{array}{l}49 \\
8 \\
\mathbf{5 7} \\
\end{array}$ & $\begin{array}{l}86,0 \\
14,0 \\
\mathbf{1 0 0}\end{array}$ \\
\hline Education & $\begin{array}{l}\text { Undergraduate } \\
\text { Master's degree } \\
\text { Doctorate degree } \\
\text { Total }\end{array}$ & $\begin{array}{l}44 \\
11 \\
2 \\
\mathbf{5 7}\end{array}$ & $\begin{array}{l}77,2 \\
19,3 \\
3,5 \\
\mathbf{1 0 0}\end{array}$ \\
\hline \multirow{7}{*}{$\begin{array}{l}\text { Profession before the } \\
\text { External Auditor } \\
\text { (Certified Public } \\
\text { Accountant) }\end{array}$} & $\begin{array}{l}\text { Sworn-in Certified } \\
\text { Public Accountant }\end{array}$ & 24 & 42,1 \\
\hline & $\begin{array}{l}\text { Independent } \\
\text { Accountant And } \\
\text { Financial Advisor }\end{array}$ & 26 & 45,6 \\
\hline & Academician & 1 & 1,8 \\
\hline & Tax Auditor & 1 & 1,8 \\
\hline & Finance Inspector & 1 & 1,8 \\
\hline & Job Analyst & 1 & 1,8 \\
\hline & Total & 57 & 100 \\
\hline \multirow{3}{*}{ Professional Title } & $\begin{array}{l}\text { Responsible } \\
\text { Co-Lead Auditor }\end{array}$ & 31 & 54,4 \\
\hline & Lead Auditor & 26 & 45,6 \\
\hline & Total & 57 & 100 \\
\hline
\end{tabular}

$N=\mathbf{5 7}$

TABLE III: INTRODUCTORY INFORMATION RELATED TO THE EXTERNAL

\begin{tabular}{|c|c|c|c|}
\hline \multicolumn{4}{|c|}{ AUDIT FIRMS } \\
\hline Information & Group & Frequency & $\%$ \\
\hline$\overline{\text { Firm }}$ & $1-9$ & 21 & 36,8 \\
\hline Operating & $10-24$ & 32 & 56,2 \\
\hline \multirow[t]{3}{*}{ Period } & 25 and over & 4 & 7,0 \\
\hline & Total & 57 & 100 \\
\hline & $5-8$ & 40 & 70,2 \\
\hline \multirow{4}{*}{$\begin{array}{l}\text { Number of } \\
\text { Firm's } \\
\text { Partners }\end{array}$} & $9-12$ & 6 & 10,5 \\
\hline & $13-15$ & 7 & 12,4 \\
\hline & 16 and over & 4 & 7,0 \\
\hline & Total & 57 & 100 \\
\hline \multirow{3}{*}{$\begin{array}{l}\text { Partnership } \\
\text { Structure of } \\
\text { the Firm }\end{array}$} & $\begin{array}{l}\text { Turkish audit firm with } \\
\text { foreign partner }\end{array}$ & 12 & 21,1 \\
\hline & $\begin{array}{l}\text { Turkish audit firm with } \\
\text { non-foreign partner }\end{array}$ & 45 & 78,9 \\
\hline & Total & 57 & 100 \\
\hline$\overline{N=57}$ & & & \\
\hline
\end{tabular}

As it is seen it Table II, $86 \%$ of the auditors those who participated in the questionnaire are male. When it comes to educational background of the participants, it is seen that $77.2 \%$ of them have a bachelor degree, $19.3 \%$ have a post graduate, and $3.5 \%$ have a doctoral degree. Before being an auditor, $42.1 \%$ of the participants were Sworn-in Certified 
Public Accountant, $45.6 \%$ of them were Independent Accountant and Financial Advisor. Furthermore, $54.4 \%$ of the auditors are responsible co-lead auditor.

As it is seen in Table III, $56.2 \%$ of the participants who participated in the questionnaire have been operating between $10-25$ years, $70.2 \%$ have partners between 5 and 8 people and $78.9 \%$ have a foreign partner.

\section{B. Descriptive Statistics}

The values of arithmetic average, standard deviation, skewness, kurtosis amongst the descriptive statistics which belong to the items constitute the scales used in the study, is presented in Table IV for the culture of quality existence level perception scale, and culture of quality existence expectation scale is presented in Table V. In the series where they display normal distribution is obtained, the value of general acceptance skewness ranges between -2 and +2 when the data is distributed normally. However, some authors claim that the skewness most probably ranges between -1 and +1 in the cases when the normalness becomes more sensitive. "Kurtosis value is generally acceepted to ranges between -2 and +2 and some authors claim that it should range between -3 and +3 " by [16].

TABLE IV: DesCRIPTIVE STATISTICS BelONG TO THE QUALITY CULTURE PERCEPTION SCALE

\begin{tabular}{lcccrr}
\hline \hline Statement & $\boldsymbol{N}$ & Mean & sd & Skewness & Kurtosis \\
\hline \hline CQPerception1 & $\mathbf{5 7}$ & 4,2281 & 0,68184 & $-1,021$ & 2,412 \\
CQPerception2 & $\mathbf{5 7}$ & 4,1404 & 0,58060 & $-0,010$ & $-0,053$ \\
CQPerception3 & $\mathbf{5 7}$ & 4,1228 & 0,59971 & $-0,560$ & 2,114 \\
CQPerception4 & $\mathbf{5 7}$ & 4,1404 & 0,66651 & $-0,915$ & 2,398 \\
CQPerception5 & $\mathbf{5 7}$ & 4,0175 & 0,76745 & $-1,013$ & 2,945 \\
CQPerception6 & $\mathbf{5 7}$ & 4,2807 & 0,67492 & $-1,128$ & 2,832 \\
CQPerception7 & $\mathbf{5 7}$ & 4,0526 & 0,61007 & $-0,513$ & 1,708 \\
CQPerception8 & $\mathbf{5 7}$ & 4,0351 & 0,75510 & $-0,317$ & $-0,429$ \\
CQPerception9 & $\mathbf{5 7}$ & 4,3684 & 0,61620 & $-0,423$ & $-0,614$ \\
CQPerception10 & $\mathbf{5 7}$ & 4,1228 & 0,82527 & $-0,433$ & $-0,854$ \\
CQPerception 11 & $\mathbf{5 7}$ & 3,1579 & 1,25056 & $-0,253$ & $-0,951$ \\
CQPerception12 & $\mathbf{5 7}$ & 3,8947 & 0,88002 & $-0,604$ & 0,668 \\
CQPerception 13 & $\mathbf{5 7}$ & 4,1228 & 0,65657 & $-0,523$ & 0,975 \\
\hline \hline N=13 & & & & \\
\hline \hline
\end{tabular}

TABLE V: DescriPTIVE STATISTICS BELONG TO THE Quality CULTuRE EXPECTATION SCALE

\begin{tabular}{lcccrr}
\hline \hline Statement & $\boldsymbol{N}$ & Mean & sd & Skewness & Kurtosis \\
\hline \hline CQExpectation1 & $\mathbf{5 7}$ & 4,6667 & 0,57735 & $-1,560$ & 1,523 \\
CQExpectation2 & $\mathbf{5 7}$ & 4,5263 & 0,60075 & $-0,872$ & $-0,183$ \\
CQExpectation3 & $\mathbf{5 7}$ & 4,4737 & 0,57025 & $-0,493$ & $-0,730$ \\
CQExpectation4 & $\mathbf{5 7}$ & 4,6491 & 0,51725 & $-1,039$ & $-0,066$ \\
CQExpectation5 & $\mathbf{5 7}$ & 4,3509 & 0,64063 & $-0,468$ & $-0,630$ \\
CQExpectation6 & $\mathbf{5 7}$ & 4,6316 & 0,55522 & $-1,197$ & 0,509 \\
CQExpectation7 & $\mathbf{5 7}$ & 4,5965 & 0,52981 & $-0,775$ & $-0,624$ \\
CQExpectation8 & $\mathbf{5 7}$ & 4,4912 & 0,60127 & $-0,731$ & $-0,392$ \\
CQExpectation9 & $\mathbf{5 7}$ & 4,6667 & 0,57735 & $-1,560$ & 1,523 \\
CQExpectation10 & $\mathbf{5 7}$ & 4,6491 & 0,55069 & $-1,292$ & 0,771 \\
CQExpectation11 & $\mathbf{5 7}$ & 3,0526 & 1,38127 & 0,071 & $-1,163$ \\
CQExpectation12 & $\mathbf{5 7}$ & 4,2807 & 0,72591 & $-0,489$ & $-0,945$ \\
CQExpectation13 & $\mathbf{5 7}$ & 4,4561 & 0,70888 & $-1,243$ & 1,401 \\
\hline \hline N=13 & \multicolumn{5}{l}{} \\
\hline \hline
\end{tabular}

Considering the Table IV and V which include the descriptive statistics belong to the scales, it is seen that the values of skewness and kurtosis which take part in the scales meet the normal distribution presupposition. Furthermore, both arithmetic average values and standard deviation values are close to each other.

\section{Testing the Hypotheses}

The fundamental hypothesis of the study, $H_{1}$ : The hypothesis of the level of understanding of the quality culture is high in the external audit firms has been tested by using the two tables above as base, general averages of both perception and expectation level has been identified as higher than 4 (as $4,4224)$. In this case, it is possible to say that the lead auditors who are responsible for quality in the external audit firms has a positive opinion about the level of understanding of the culture of quality in the auditing companies. In this case, it is possible to say that $\mathrm{H}_{1}$ hypothesis to be approved.

The second fundamental hypothesis of the study was $\mathrm{H}_{2}$ : The expectations regarding the quality culture were completely met in the external audit firms. In this hypothesis has been analyzed by paired sample $t$ test. The expression of paired means collecting two data from one participant of the questionnaire. Thus, the existing culture of quality and the expectation of the participant have been asked separately and then, meeting the expectations by conceptions has been observed with this test.

In the external audit firms, whether the expectations about the culture of quality are completely met or not, have been examined by means of level of the culture of quality and perception scales which take part in the questionnaire form. In this context, the results of the paired sample $t$ test is presented in Table VI which analyzed whether there is a difference between quality control level total "perception scores" and total "expectation scores".

TABLE VI: PAIRED SAMPLE T TEST

\begin{tabular}{|c|c|c|c|c|c|c|c|}
\hline & Mean & $N$ & sd & $\begin{array}{c}\text { Mean } \\
\text { Differences }\end{array}$ & $t$ & sd & $p$ \\
\hline Perception & $\begin{array}{l}\vec{b} \\
\stackrel{.}{心} \\
\tilde{\omega}\end{array}$ & un & $\begin{array}{l}\text { 片 } \\
\text { 岕 }\end{array}$ & $\underset{⿱ 亠 巾}{\stackrel{b}{N}}$ & d & un & \& \\
\hline Expectation & 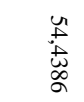 & un & $\begin{array}{l}\stackrel{+}{a} \\
\stackrel{0}{d} \\
\sigma\end{array}$ & & & & \\
\hline
\end{tabular}

Average of the perception points is registered to be 49,5263 and the average of the expectation points registered to be 54,4386 , and there are approximately 5 points of difference between each other. In a sense, average of the perception points is lower than the average of expectation points, and there is a meaningful difference between each other statistically. $(p=0,000)$. In this case, although it is possible to state that the perceptions regarding the level of the culture of quality in the external audit firms could not met the expectations, when it comes to level of the meeting the expectations, $(49,5263 / 54,4386=0,8546)$ it is seen that the level of the meeting the expectations is approximately $85 \%$. In this case, it is possible to say that the expectations have been met with a very high level.

When the results of these two hypotheses are tackled 
together, it is possible to say; that the level of the culture of quality in the external audit firms is at a very good level, that the expectations could not met completely but it is still at $85 \%$ of level of meeting the expectation and that the results are not negative.

\section{CONCLUSION}

It takes time for a culture of quality, which is a set of values and shared by all the individuals of an external audit firm, to gain depth to a certain extent. Studies regarding the quality improvement become successful in the cultures which have suitable values, beliefs and attitudes for external auditing. Composing the culture of quality can be obtained with a cultural change which means changing attitudes, behaviors and values but not with a structural change. The external audit firms which are able to compose the culture of quality or quality environment assure the quality of the auditing.

According to the results of this study which has been conducted regarding the determination of the existing culture of quality levels in the external audit firms in Turkey, the fundamental hypothesis of the study $\mathrm{H}_{1}$ : It is possible to say that the hypothesis of "the level of understanding of the quality culture is high in the external audit firms" has been approved. In this context, considering the culture of quality, it is concluded that the level of understanding of the culture of quality in the external audit firms in Turkey is at the desired level. Another objective of the study " $H_{2}$ : The hypothesis of "the expectations regarding the quality culture were completely met in the external audit firms" has been partially approved at the end of the analysis performed. In other words, although the expectations about the culture of quality could not be met completely, the level of meeting the expectations $(85 \%)$ has been registered as pretty high.

Let us not forget that these results of the study are the opinions of the lead auditors who are responsible for quality in the auditing companies. Therefore, there is no doubt that the results of this study are valid under specific constraints. In the upcoming studies which will have much wider frameworks, it is possible to say that this subject will become much clear. On the subject of the culture of quality in external auditing, the opinions of the auditors who have different titles are not known. Once again, it is not known that whether there is a difference between the foreign-origin auditing firms and the native auditing firms or not. The relationship between the culture of quality and quality is another subject which can be researched. Such subjects remain untouched in their field and wait for the interests of both native and foreign researchers.

APPENDIX

SURVEY FORM: GENERAL INFORMATION

\begin{tabular}{|c|c|}
\hline \multicolumn{2}{|l|}{ Personal Information } \\
\hline Sex & ( ) Female \\
\hline Age & ( )30 and under ( )31-35 ( )36-40 ( )41-45 ( )46-50 ( )51-55 ( )56-60 ( )61 and over \\
\hline Experience in the audit field & 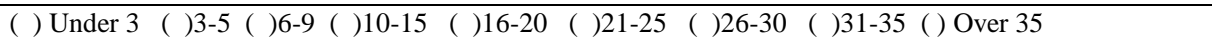 \\
\hline Education & ( ) Undergraduate ( ) Master's degree \\
\hline $\begin{array}{l}\text { Profession Before the External Auditor } \\
\text { (Certified Public Accountant) }\end{array}$ & $\begin{array}{l}\text { ( ) Sworn-in certified puplic accountant ( )Independent accountant and financial advisor ( )Academician } \\
\text { ( ) Others }\end{array}$ \\
\hline Professional Title & ( ) Responsible Co-Lead Auditor ( ) Lead Auditor \\
\hline \multicolumn{2}{|l|}{ Firm Information } \\
\hline \multicolumn{2}{|l|}{ Firm Operating Period } \\
\hline \multicolumn{2}{|l|}{ Number of Firm's Partners } \\
\hline Partnership Structure of the Firm & $\begin{array}{l}\text { ( ) Turkish audit firm with foreign partner } \\
\text { ( ) Turkish audit firm with non-foreign partner }\end{array}$ \\
\hline
\end{tabular}

QUALITY CULTURE PERCEPTION SCALE

\begin{tabular}{|c|c|c|c|c|c|c|}
\hline \multicolumn{7}{|c|}{ Please indicate your thoughts about the being level of the following factors in your firm. } \\
\hline & 1:None, 2:Low Level, 3:Neither agree nor disagree, 4:High Level 5:Perfec & & & & & \\
\hline Abbreviation & Statement/Question & 1 & 2 & 3 & 4 & 5 \\
\hline QCPerception 1 & Understanding of commitment to quality of responsibles & & & & & \\
\hline QCPerception2 & Effective leadership skills of responsibles & & & & & \\
\hline QCPerception3 & Understanding of focusing firms goals of employees & & & & & \\
\hline QCPerception 4 & Understanding of being consistent in achieving the firm's objectives & & & & & \\
\hline QCPerception5 & Thought of ensuring involvement of employees in decision-making & & & & & \\
\hline QCPerception6 & Giving value to employees by management & & & & & \\
\hline QCPerception7 & Understanding of analysis-oriented decision-making in management decisions & & & & & \\
\hline QCPerception 8 & Understanding of social responsibility of responsible & & & & & \\
\hline QCPerception 9 & Understanding of continuous improvement of providing service & & & & & \\
\hline QCPerception 10 & Continuous learning approach of employees & & & & & \\
\hline QCPerception 11 & Understanding of working oriented on customer requests and needs in providing service & & & & & \\
\hline QCPerception 12 & $\begin{array}{l}\text { Understanding of company's effective communication with work the specialized agencies } \\
\text { which worked }\end{array}$ & & & & & \\
\hline QCPerception 13 & Process-oriented management understanding in firm & & & & & \\
\hline
\end{tabular}

QUALITY CULTURE EXPECTATION SCALE

Please indicate your personal thoughts about the importance of the following factors in building quality culture of firm. 1: Strongly disagree, 2: Disagree, 3: Neither agree nor disagree, 4: Agree, 5: Strongly agree 


\begin{tabular}{|l|l|l|l|l|l|l|}
\hline QCExpectation 3 & Understanding of focusing firms goals of employees is important & & & & \\
\hline QCExpectation 4 & Understanding of beign consistent in achieving the firm's objectives is important & & & & & \\
\hline QCExpectation 5 & Thought of ensuring involvement of employees in decision-making is important & & & & & \\
\hline QCExpectation 6 & Giving value to employees by management is important & & & & & \\
\hline QCExpectation 7 & Understanding of analysis-oriented decision-making in management decisions is important & & & & & \\
\hline QCExpectation 8 & Understanding of social responsibility of responsibles is important & & & & & \\
\hline QCExpectation 9 & Understanding of Continuous improvement of providing service is important & & & & \\
\hline QCExpectation 10 & Continuous learning approach of employees is important & & & & & \\
\hline QCExpectation 11 & $\begin{array}{l}\text { Understanding of working oriented on customer requests and needs in providing service is } \\
\text { important }\end{array}$ & & & & \\
\hline QCExpectation 12 & $\begin{array}{l}\text { Understanding of company's effective communication with work the specialized agencies } \\
\text { which worked is important }\end{array}$ & & & & & \\
\hline QCExpectation 13 & Process-oriented management understanding in firm is important & & & & \\
\hline
\end{tabular}

\section{REFERENCES}

[1] De A. L. Elizabeth, "Auditor size and audit quality," Journal of Accounting \& Economics, vol. 3, no. 3, pp. 183-199, 1981.

[2] K. ve diğerleri Johnstone, Auditing: A Risk-Based Approach to Conducting a Quality Audit, 9th ed. USA: South-Western/Cengage Learning, 2013.

[3] P. Fatma, "Kalite kültürünü etkileyen faktörler üzerine bir derleme," Dokuz Eylül Üniversitesi Sosyal Bilimler Enstitüsü Dergisi, vol. 6, no. 3, pp. 167-183, 2004.

[4] T. Daniel et al., "A test of audit pricing in the small-client segment of the U.S. audit market," The Accounting Review, vol. LXII, no. 1, pp. 145-157, 1987.

[5] R. Earl et al., "Auditor changes: A joint test of theories relating to agency costs and auditor differentiation," The Accounting Review, vol. LXIII, no. 4, pp. 663-682, 1988.

[6] O. Sadiye, "Quality control of the audit service in increasing the effectiveness of external auditing and study on audit fims in Turkey," Ph.D. dissertation, İstanbul University, Sosyal Bilimler Enstitüsü, İstanbul, Turkey, 2003.

[7] O. Mustafa, "Bağımsız denetimin denetimi," SPK Yeterlik Etüdü, Kasım, pp. 1-5, 2007.

[8] V. Ludmila, "The development and improvement of the quality system of audit services in Latvia," Regional Formation and Development Studies, vol. 11, pp. 244-253, 2013.

[9] D. Engin and A. Esra, "Uzaktan eğitim modelinde muhasebe derslerinin verimliliği," vol. 33, Muhasebe Sempozyumu, Bildiriler Kitabı, Eskişehir, 2014.

[10] G. David, Testing Statistical Assumptions, USA: Statistical Associates Publishing, 2012.

[11] F. M. Gryna and M. A. Watson, "Wuality culture in small business: Four case studie," Quality Progress Milwaukee, vol. 34, no. 1, pp. 41-48, Jan. 2001
[12] R. D. Donald and G. A. Giroux, "Determinants of audit quality in the public sector," The Accounting Review, vol. 67, no. 3, pp. 462-479, 1992.

[13] S. Jale, "Quality control on external and internal auditing: Two separate research related with certificated public accountant firms and large industrial corporations," Ph.D. dissertation, Çukurova University, Sosyal Bilimler Enstitüsü, Adana, Turkey, 2003.

[14] S. Serpil, "The role of the public oversight board in boosting the quality of the independent auditing: Study on independent auditing firms," $\mathrm{Ph} . \mathrm{D}$. dissertation, Süleyman Demirel University, Sosyal Bilimler Enstitüsü, Isparta, Turkey, 2011.

[15] Y. Alparslan, "Bağımsız Dış Denetim Kuruluşlarına Yönelik Gözetim ve Denetim Etkinliğinin Bağımsız Dış Denetim Kalitesi İle İlişkisi: Türkiye Değerlendirmesi," Cukurova Üniversitesi Sosyal Bilimler Enstitüsü Dergisi, vol. 22, no. 1, pp. 465-480, 2013.

[16] M. Naresh and B. David, Marketing Research an Applied Approach, 3th ed. England: Prentice Hall, 2007.

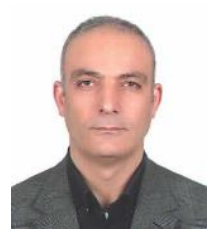

Engin Dinç was born in 1966 in Trabzon, Turkey. He finished PhD in accounting at Karadeniz Technical University, Turkey. In addition, he is working as a "professor in accounting" at Karadeniz Technical University, Turkey. His research interests are Auditing, Cost Accounting, General Accounting, IFRS.

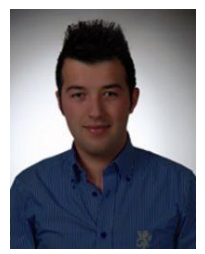

Yasin Şeker was born in Adana, Turkey in 1988. He finished undergraduate level in Turkey at Hitit University, FEAS, Business Administration. He finished the MSc in accounting at Karadeniz Technical University, Turkey. In addition, he is working as a 'research assistant' at Hitit University in Çorum, Turkey. His research interests are auditing, genaral accounting, standards on accounting and auditing, and accounting 